(C) Е.В. Фесенко ${ }^{1}$, С.С. Павлов ${ }^{1}$

${ }^{1}$ Технічний університет «Метінвест Політехніка», Маріуполь, Україна

\author{
ОБГРУНТУВАННЯ ЗАСТОСУВАННЯ ВИБУХОВОГО \\ РОЗВАНТАЖЕННЯ ПОРІД ПОКРІВЛІ ДЛЯ ПІДВИЩЕННЯ \\ ЕФЕКТИВНОСТІ РОБОТИ РАМНОГО МЕТАЛЕВОГО КРІПЛЕННЯ
}

(C) E. Fesenko ${ }^{1}$, Ye. Pavlov ${ }^{1}$

${ }^{1}$ Technical University Metinvest Polytechnic, Mariupol, Ukraine

\title{
VALIDATION OF THE USE OF MINE ROOF ROCKS EXPLOSIVE UNLOADING TO INCREASE THE EFFICIENCY OF METAL FRAME SUPPORT
}

Мета. Вивчення особливостей і ефективності роботи кріплення рамного трапецієподібного посиленого з центральною стійкою підвищеного опору з різних типів несучих профілів під дією зовнішнього навантаження.

Методи дослідження. Проведено чисельне моделювання методом скінченних елементів за допомогою програмного комплексу Ліра. Використано модель кріплення у вигляді плоскої рами, завантаженої зовнішніми зусиллями, прикладеними до верхняка. Проаналізовано напружено-деформований стан небезпечних перерізів конструкції за допомогою визначення в них значень внутрішніх силових факторів.

Результати. На основі розробленої методики і розрахункової схеми проведено порівняння ефективності роботи рамного трапецієподібного посиленого кріплення 3 центральною стійкою під дією різних видів зовнішнього навантаження та з використанням різних типів несучих елементів конструкції. Розрахована несуча здатність кріплення, проведений підбір та конструювання несучих елементів. Розрахований параметр працездатності кожного із розглянутих варіантів кріплення, який дозволив обгрунтувати доцільність застосування вибухового розвантаження порід покрівлі для підвищення ефективності роботи кріплення.

Наукова новизна. Розроблені розрахункова схема та методика для визначення несучої здатності рамного трапецієподібного кріплення з центральною стійкою під дією різних типів зовнішнього навантаження. Проведений аналіз конструкції з використанням запропонованого параметру працездатності та доведено доцільність вибухового розвантаження порід покрівлі із застосуванням коробчастого замкнутого профілю прокату для підвищення ефективності роботи рамного кріплення.

Практичне значення. На основі запропонованої розрахункової схеми проведений аналіз роботи рамного трапецієподібного кріплення з центральною стійкою, який дозволив обгрунтувати величину несучої здатності кріплення в різних умовах його роботи, провести конструювання та підбір типорозмірів несучих елементів, довести, що використання для несучих елементів кріплення замкнутого коробчастого профілю з вибуховим розвантаженням порід покрівлі забезпечить суттєву економію металопрокату, яка може досягати 300 і більше тон на кілометр виробки.

Ключові слова: рамне кріплення, чисельне моделювання, гірський тиск, несуча здатність, несучий елемент, працездатність. 
Вступ. Проблема забезпечення стійкості підготовчих виробок при розробці вугільних родовищ Донбасу в значній мірі впливає на ефективність роботи гірничих підприємств. Збільшення глибини розробки вугільних родовищ призводить до ускладнення гірничо-геологічних умов і підвищення інтенсивності гірського тиску, нерівномірності зсувів порід і формування навантаження на кріплення, особливо в зоні впливу очисних робіт. Все це нерідко ускладнюється низькою якістю встановлення кріплення у виробці (великі пустоти закріпного простору, відсутність, або погана якість забутовки, нерівний контур виробки и т.і.) $[1,2]$.

В таких умовах типові методи проектування і існуючі конструкції металевого кріплення виявляються неефективними, що підтверджується шахтними інструментальними вимірами і спостереженнями за станом кріплення. Так, щорічні обсяги перекріплення складають близько $15 \%$ від протяжності виробок, що підтримуються [3] і ця цифра дедалі зростає. Перехід на використання «важких» профілів СВП-27 і 33 в рамних кріпленнях і збільшення щільності установки до 2 і більше рам/м підвищили витрату металу до 600 ... 700 т/км, проте не призвели до істотного підвищення надійності і стійкості підтримуваних виробок. У той же час нерідкі випадки підвищеного запасу міцності окремих елементів конструкції, що призводить до необгрунтованої перевитрати металу. Через незадовільний стан виробок і необхідність їх ремонту різко зростають трудові і матеріальні витрати, уповільнюються гірничо-підготовчі і очисні роботи, знижуються технікоекономічні показники шахти.

Переважну більшість кріплень підготовчих виробок в даний час виготовляють зі спеціального взаємозамінного шахтного профілю СВП. В середньому витрачається близько 300-400 т металопрокату на кожен кілометр виробки. При цьому зведення кріплення, як правило, здійснюють вручну, що при значних розмірах виробки (понад 11-12 м²) досить трудомістко, оскільки маса елемента кріплення (верхняка), який необхідно встановити на висоті 3,5-4 м, може досягати $140 \ldots 160$ кг. Тому так актуальна проблема зниження вартості і металоємності кріплення для гірничодобувної промисловості.

Дослідження існуючих конструкцій рамного податливого кріплення [4] дозволили виявити основні їх недоліки та запропонувати нове кріплення рамне трапієподібне посилене (КРТП), яке складається з двох бічних і центральної стійок 3 спецпрофилю СВП і верхняка 3 консолями, виконаного з замкнутого профілю прямокутного обрису (або традиційного профілю СВП). При цьому центральна стійка має підвищений опір податливості, а верхняк в місці з'єднання з центральною стійкою забезпечений елементом посилення [5-7].

Слід звернути увагу на вибір сталевого прокату для елементів кріплення. У роботах $[8,9]$ виконано аналіз існуючих серійних профілів металопрокату і показано, що найбільш технологічним і ефективним для рамного кріплення $\epsilon$ замкнутий тонкостінний профіль прямокутного обрису. Його міцність на вигин (за умови рівності мас 1 п. м.) вище, ніж у стандартних спецпрофілів типу СВП того ж перетину в 1,5 - 2 рази, а при крученні - в 16 - 27 разів. 
Одним з перспективних способів підвищення стійкості виробки і стану кріплення $є$ перерозподіл навантаження на рамне кріплення за допомогою вибухового розвантаження масиву від напружень в покрівлі гірничої виробки [10]. Цей спосіб здатен достатньо ефективно підвищити несучу здатність рамного кріплення при правильному застосуванні, він відносно простий та дешевий, але потребує високої кваліфікації виконавців, більш досконалого вивчення параметрів та розробки детальної технології робіт.

Постановка проблеми. Дослідження роботи кріплення КРТП та його основних параметрів залежно від схеми зовнішнього навантаження, впливу вибухового розвантаження порід покрівлі на несучу здатність довели ефективність запропонованих рішень, але залишились не з'ясованими питання визначення параметрів кріплення КРТП та ефективності його роботи при застосуванні вибухового розвантаження порід покрівлі у порівнянні з традиційною розрахунковою схемою, регламентованою [11]. Крім того не досліджена ефективність застосування кріплення КРТП з замкнутого коробчастого профілю прокату при різних схемах зовнішнього навантаження, у порівнянні з такою самою конструкцією, виконаною з профілю СВП.

У зв'язку з цим, мета досліджень полягає у вивченні особливостей і ефективності роботи КРТП з різних типів несучих профілів під дією зовнішнього навантаження. Об'сктом досліджень $є$ рамне податливе трапецієподібне кріплення 3 верхняком, який містить консолі, і центральною стійкою з посиленим опором піддатливості, а предмет досліджень - несуча здатність і технічні параметри цього кріплення в залежності від схеми зовнішнього навантаження.

Завданнями досліджень $\epsilon$ розрахунок і обгрунтування параметрів КРТП при різних схемах зовнішнього навантаження на кріплення.

Основна ідея досліджень полягає в урахуванні впливу схеми зовнішнього навантаження та типу несучих елементів на несучу здатність кріплення і ефективність його роботи.

Основний матеріал. Для визначення параметрів КРТП виконаємо розрахунок даної конструкції з використанням методу скінченних елементів за допомогою програми Ліра. Розглянемо два варіанти роботи кріплення: 1 - під дією вертикального навантаження, зумовленого гірським тиском, яке має вигляд параболи (схема, регламентована нормативним документом [11]); 2 - вертикальне навантаження на кріплення формується в результаті вибухового розвантаження порід покрівлі, яке здійснюється наступним чином (рис. 1). У покрівлю виробки бурять три шпури, вибої двох з яких розташовані посередині консольних виступів верхняка, а один - над центральною стійкою. Шпури заряджають зарядами розпушування, та підривають. Таким чином, підірвана порода формує зовнішнє навантаження на кріплення, як показано на рис. 1. 


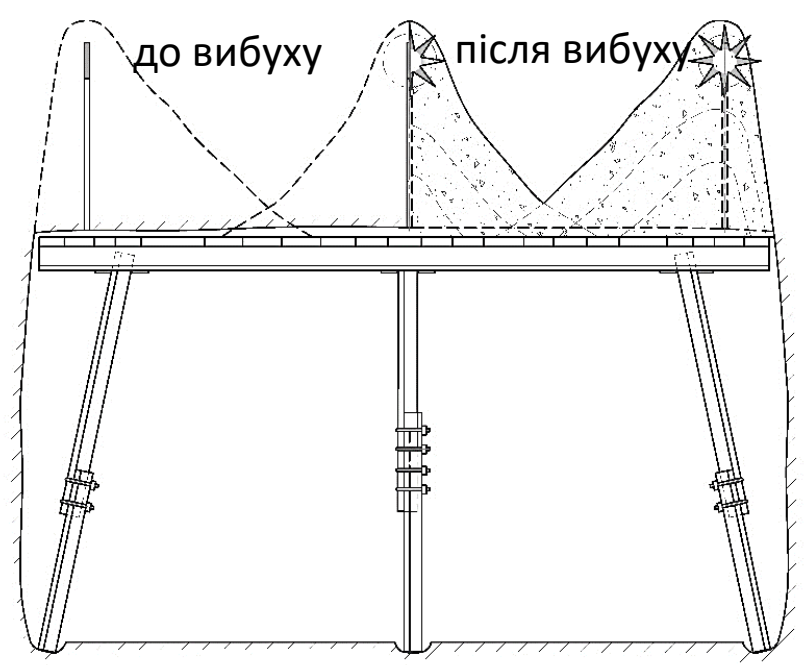

Рис. 1. Схема вибухового розвантаження порід покрівлі гірничої виробки

На рис. 2 представлені розрахункові схеми кріплення КРТП для обох схем зовнішнього навантаження.

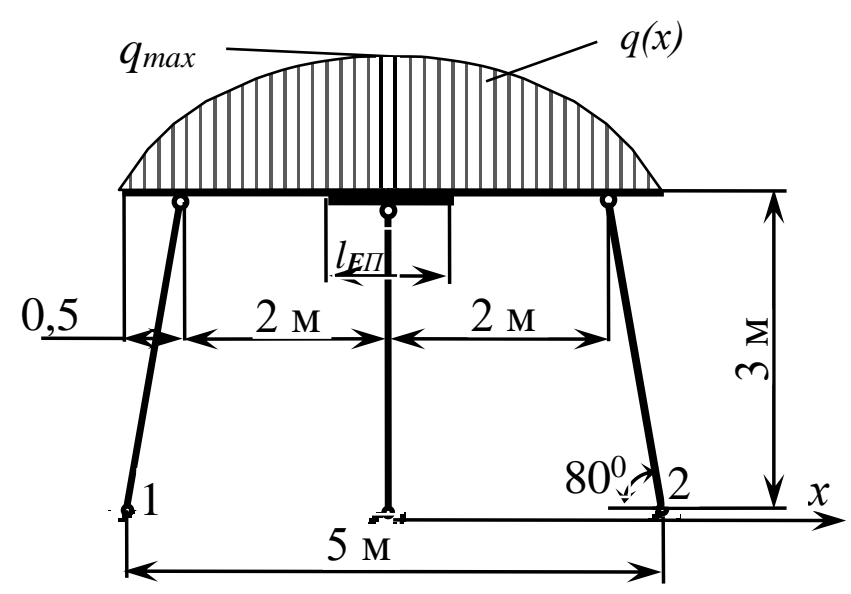

a)

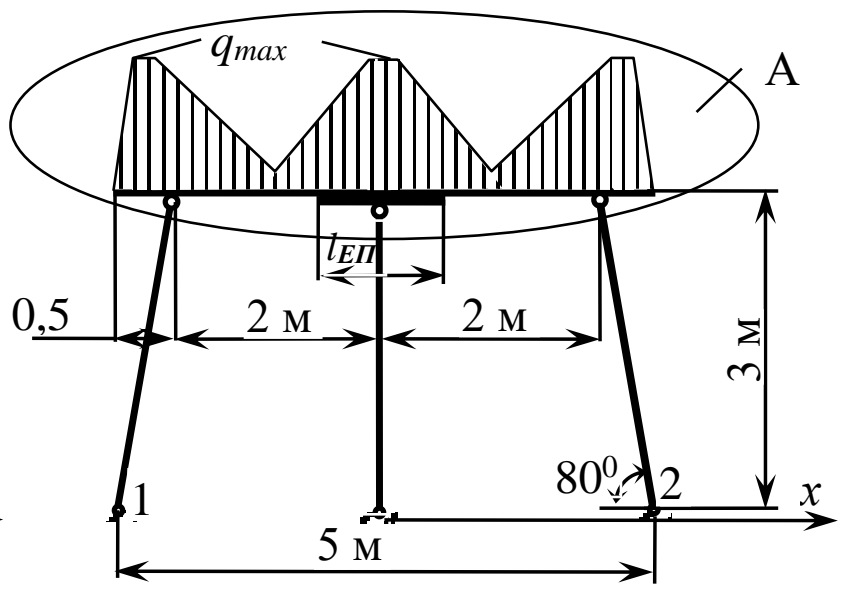

б)

Вузол

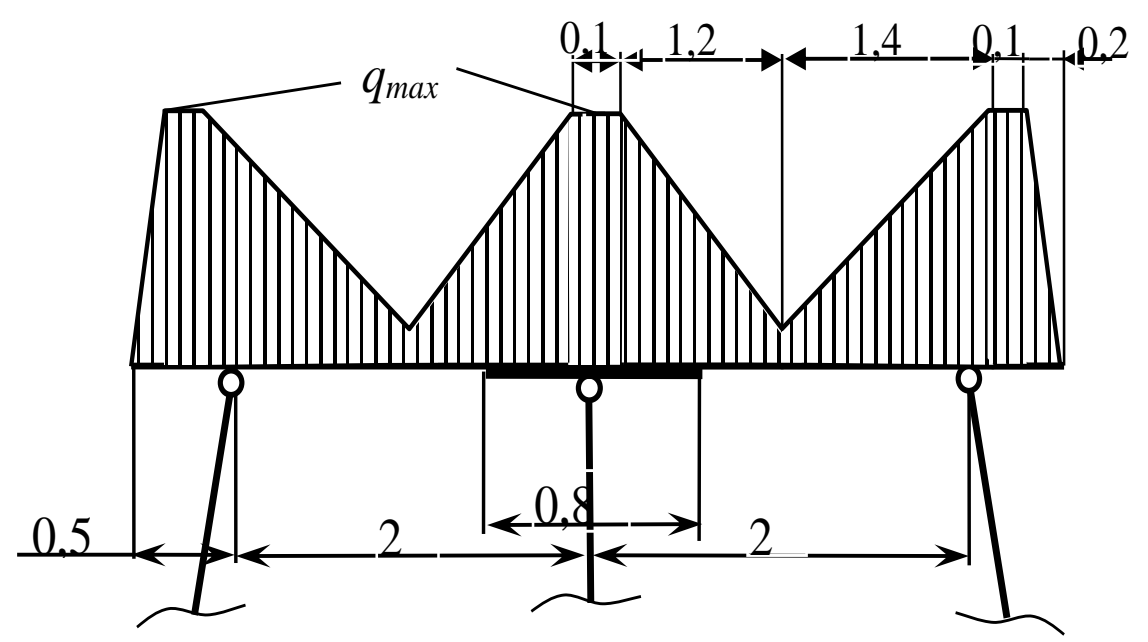

Рис. 2. Розрахункова схема кріплення КРТП: а) - за рекомендаціями [11];

б) - при вибуховому розвантаженні порід покрівлі; в) - вузол А 
Висота кріплення прийнята $h=3$ м, можлива величина податливості $\Delta U=1000$ - 1500 мм. Такі геометричні характеристики дозволяють використовувати кріплення КРТП в умовах великих зсувів порід контуру в зоні впливу очисних робіт. Площа поперечного перерізу такого кріплення $S=13,5 \mathrm{~m}^{2}$. Кут нахилу стійок складає $80^{\circ}$, довжина консолей верхняка прийнята рівною 0,5 м. Консолі забезпечують більш рівномірний розподіл навантаження на верхняк, зменшення згинальних моментів і запобігання прокидання породи з покрівлі на стійки кріплення, особливо в районі сполучення кріплення з лавою.

Нижні вузли 1, 2 стійок спираються на підошву виробки і прийняті як нерухомі шарніри. З'єднання стійок 3 верхняками також прийнято шарнірним. Елемент посилення верхняка має довжину $l_{E \Pi}$ і створює на ділянці посилення підвищений момент інерції $J_{x}$ і момент опору $W_{x}$. Опір вузлів піддатливості на центральній стійці кріплення прийнятий у два рази більший, ніж на кожній з бокових: $N_{C Ц}=2 N_{C Б}$, тобто на центральній стійці передбачена установка двох стандартних вузлів піддатливості з подвоєним опором. Межа міцності сталі, з якої виготовлені елементи кріплення, прийнята $R_{y}=240$ МПа. Раціональна довжина елемента

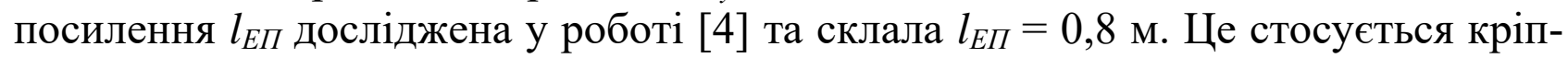
лення, верхняк якого виконано з замкнутого коробчастого профілю. У разі використання профілю СВП елемент посилення, як правило, не встановлюється оскільки в цьому випадку складно забезпечити ефективну спільну роботу верхняка та елемента посилення через недосконалість існуючих елементів 3'єднання спеціальних профілів СВП, що призводить до ненадійної роботи таких сполучень.

Згідно нормативного документу, який регламентує розрахунки кріплень гірничих виробок [11], зовнішнє навантаження на кріплення має вигляд квадратичної параболи з максимальним значенням $q_{\max }$ в центрі верхняка (рис. 2, а):

$$
q(x)=q_{\max }\left(1-\frac{x^{2}}{a^{2}}\right),
$$

де $x^{2}$ - поточна горизонтальна координата, відрахована від центру виробки (рис. $1, \mathrm{a}) ; a$ - половина ширини виробки $(a=2,5 \mathrm{~m})$;

У разі застосування вибухового розвантаження порід покрівлі зовнішнє навантаження на кріплення буде формуватися згідно схеми, наведеної на рис. 2, б, в.

Визначимо несучу спроможність кріплення КРТП, завантаженого по схемі (рис. 2, а), якщо його несучі елементи виконані з профілю СВП-33. Для цього прикладемо до верхняка одиничне вертикальне параболічне навантаження величиною $Q=1 \mathrm{\kappa H}$. Тоді $q_{\max }=0,3 \mathrm{\kappa H} / \mathrm{м}$. Епюра згинальних моментів, отримана у програмі Ліра, має вигляд, показаний на рис. 3. Значення екстремальних згинальних моментів $M_{1}$ та $M_{2}$ склали відповідно 95,8 Н·м та 46,1 Н·м, поздовжні сили у верхняку $N_{1}=N_{2}=45,68 \mathrm{H}$. Розрахунок будемо вести для перерізу з більшим значенням моменту, тобто для $M_{l}=95,8 \mathrm{H} \cdot$ м. Сумарні напруження $\sigma$ в небезпечному перерізі залежать від сумісної дії згинальних моментів $M$ та поздовжніх сил $N$ i не повинні перевищувати розрахункового опору сталі $R_{y}$ : 


$$
\sigma=\frac{M}{W}+\frac{N}{A} \leq R_{y}
$$

де $M$ і $N$ відповідно згинальний момент і поздовжня сила у небезпечному переpiзi; $W$ - момент опору несучого профіля (для СВП-33 $W=133,5 \mathrm{~cm}^{3}$ ); $A$ - площа перерізу несучого профілю (для СВП-33 $A=42,53 \mathrm{~cm}^{2}$ ); $R_{y}$ - межа міцності сталі, МПа.

Таким чином,

$$
\sigma=\frac{95,8}{133,5}+\frac{45,68 \cdot 10^{-2}}{42,53}=0,728 \text { МПа }
$$

Враховуючи що $R_{y}=240$ МПа, навантаження на кріплення можна збільшити у $240 / 0,728=330$ разів, тобто при даній схемі несуча спроможність кріплення КРТП складе $P=330$ кН.

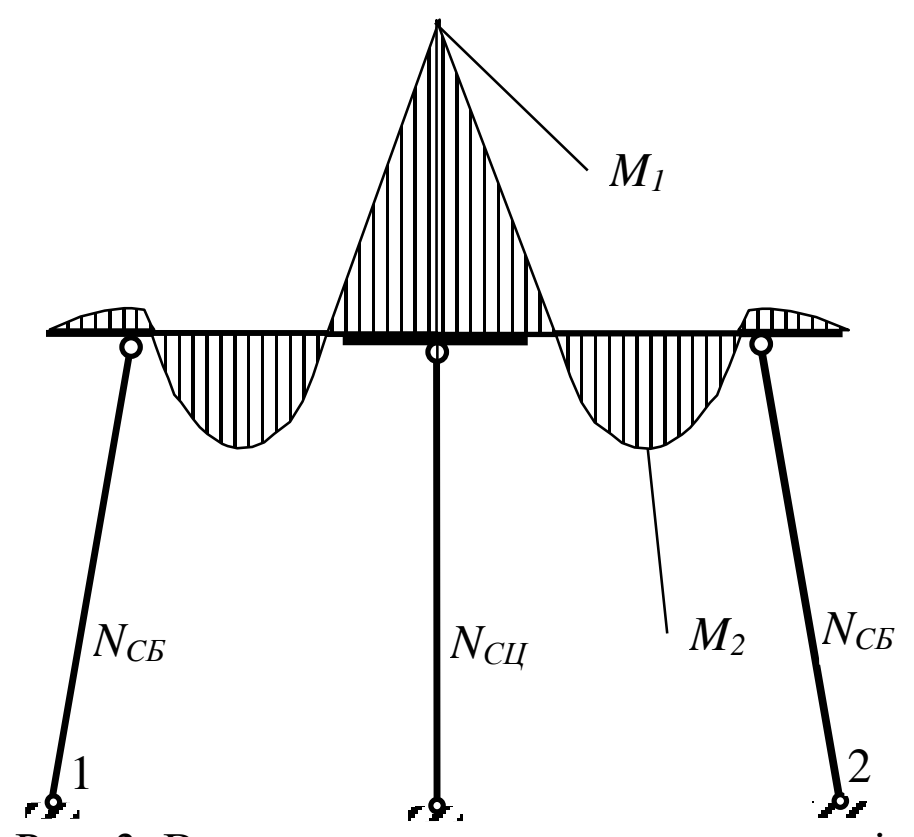

Рис. 3. Вигляд епюри згинальних моментів

Виконаємо порівняльний розрахунок КРТП на таку саму несучу здатність $P=330$ кН, якщо у покрівлі виробки зроблено вибухове розвантаження порід. У цьому випадку зовнішнє навантаження буде прикладене у відповідності до схеми (рис. 2, б, в). Згинальні моменти та поздовжні сили у небезпечних перерізах дорівнюють $M_{l}=19,64 \mathrm{\kappa H} \cdot \mathrm{M}, M_{2}=8,09 \kappa \mathrm{\kappa} \cdot \mathrm{M}, N_{l}=N_{2}=15,95 \kappa \mathrm{H}$. Розрахуємо напруження $\sigma$ в найбільш небезпечному перерізі 1 за формулою (2). Для профіля СВП33 вони складуть $\sigma=150,85$ МПа при допустимих $R_{y}=240$ МПа, тобто запас міцності дорівнює $240-150,85=89,15$ МПа. Виходячи з цього, можна зменшити типорозмір спецпрофілю з СВП-33 до СВП-27. Тоді напруження складуть $\sigma=$ 200,64 МПа. Тобто міцність кріплення буде забезпечена. Використання профілю СВП-22 призведе до зростання напружень у найбільш небезпечному перерізі до $\sigma=268,3$ МПа, що неприпустимо. Таким чином, вибухове розвантаження порід покрівлі кріплення КРТП дає змогу при збереженні несучої здатності $P=330 \mathrm{\kappa H}$, 
замінити профіль СВП-33 на СВП-27, суттєво зекономивши метал. Оскільки довжина елементів кріплення КРТП складає приблизно 14 м, при виготовленні його зі спецпрофілю СВП-33, маса складе 14·33,39= 467,5 кг. (33,39 кг - маса 1 погонного метра профілю СВП-33). Заміна профілю СВП-33 на СВП-27 зменшує масу кріплення до $14 \cdot 27,0=378$ кг. Таким чином економія на кожній рамі кріплення складає 467,5 - 378 =89,5 кг металопрокату. Якщо крок встановлення кріплення у виробці становить $a=1$ м, економія на 1 км виробки складе 89,5 т, або $20 \%$.

Проведемо розрахунки кріплення КРТП при використанні профілів СВП 27, 22 та 19 за схемою, регламентованою [11] (рис. 2, а). Визначимо у кожному випадку згинальні моменти $M$ та поздовжні сили $N$ у небезпечному перерізі, несучу спроможність $P$ та масу конструкції і порівняємо отримані результати з кріпленням, зовнішнє навантаження на яке формується в результаті вибухового розвантаження порід покрівлі (рис. 2, б, в). Результати розрахунків зведено у табл. 1 .

Таблиця 1

Розрахункові параметри кріплення КРТП зі спецпрофілю СВП

\begin{tabular}{|l|c|c|c|c|c|c|}
\hline $\begin{array}{c}\text { Схема за- } \\
\text { ванта- } \\
\text { ження крі- } \\
\text { плення }\end{array}$ & $\begin{array}{c}\text { Зусилля у небез- } \\
\text { печному перерізі }\end{array}$ & $\begin{array}{c}\text { ТиП } \\
\text { профілю }\end{array}$ & $\begin{array}{c}\text { Маса конс- } \\
\text { трукції, кг }\end{array}$ & $\begin{array}{c}\text { Економія } \\
\text { металу, } \\
\text { кг/раму }\end{array}$ & $\begin{array}{c}\text { Економія } \\
\text { металу, } \\
\%\end{array}$ \\
\hline \multicolumn{7}{|c|}{ Несуча здатність кріплення $P=330$ кН } \\
\hline згідно [11] & 31,61 & 15,07 & СВП-33 & 467,5 & - & - \\
\hline ВРПП* & 19,64 & 15,95 & СВП-27 & 378,0 & 89,5 & 20 \\
\hline \multicolumn{7}{|c|}{ Несуча здатність кріплення $P=250$ кН } \\
\hline згідно [11] & 23,94 & 11,40 & СВП-27 & 378,0 & - & - \\
\hline ВРПП & 14,88 & 12,09 & СВП-22 & 306,6 & 71,4 & 20 \\
\hline \multicolumn{7}{|c|}{ Несуча здатність кріплення $P=180$ кН } \\
\hline згідно [11] & 17,20 & 8,22 & СВП-22 & 306,6 & - & - \\
\hline ВРПП & 10,70 & 8,70 & СВП-17 & 239,4 & 67,2 & 22 \\
\hline \multicolumn{7}{|c|}{ Несуча здатність кріплення $P=150$ кН } \\
\hline згідно [11] & 14,30 & 6,85 & СВП-19 & 268,8 & - & - \\
\hline ВРПП & 8,92 & 7,25 & СВП-14 & 205,8 & 63,0 & 23 \\
\hline
\end{tabular}

*Примітка. ВРПП - вибухове розвантаження порід покрівлі

Проведені розрахунки підтвердили високу ефективність використання вибухового розвантаження порід покрівлі для покращення параметрів кріплення КРТП. При однакових показниках несучої здатності економія металу складає від 20 до 23 \% залежно від типу профіля СВП, що використовується. Це дає змогу заощадити від 63 до 89,5 тон металу на кожному кілометрі гірничої виробки при кроці встановлення кріплення $a=1 \mathrm{~m}$. За умови використання однакових профілів СВП, вибухове розвантаження порід дасть змогу суттєво підвищити несучу 
здатність кріплення у порівнянні зі звичайною схемою зовнішнього навантаження. Слід відмітити, що недоліком використання профілів СВП є неможливість гнучкого підбору несучих елементів через невелику кількість існуючих типорозмірів. Це призводить у ряді випадків до надмірного запасу міцності, а значить, до перевитрати металу на одиницю несучої здатності конструкції.

На наступному етапі проведені дослідження зміни параметрів КРТП при використанні несучих елементів із замкнутого коробчастого профілю прокату замість спецпрофілю СВП. Таке кріплення містить елемент посилення довжиною $l_{E \Pi}=0,8$ м, встановлений над центральною стійкою способом «труба в трубі». Це дає змогу оптимально підбирати параметри несучих профілів для підвищення ефективності конструкції. Для коректного порівняння проведемо розрахунки кріплення для тих самих значень несучої здатності, що і при використанні профілів СВП, тобто $P_{1}=330 \mathrm{\kappa H}, P_{2}=250 \kappa \mathrm{H}, P_{3}=180 \kappa \mathrm{H}, P_{4}=150$ кН. Порядок розрахунків наступний. Після завантаження конструкції визначеною величиною: $P_{1} \ldots P_{4}$ по схемам рис. 2, за допомогою програми Ліра визначались згинальні моменти $M$ та поздовжня сила $N$ у небезпечних перерізах конструкції, по яким відбувався підбір міцних елементів кріплення. Результати розрахунків зведено до табл. 2.

Таблиця 2

Розрахункові параметри кріплення КРТП з коробчастого профілю прокату

\begin{tabular}{|c|c|c|c|c|c|c|c|c|c|}
\hline \multirow{2}{*}{ 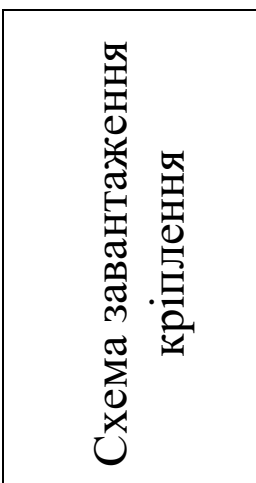 } & \multicolumn{4}{|c|}{$\begin{array}{c}\text { Зусилля у } \\
\text { небезпечних } \\
\text { перерізах }\end{array}$} & \multicolumn{2}{|c|}{$\begin{array}{c}\text { Тип несучого } \\
\text { профілю }\end{array}$} & \multirow{2}{*}{ 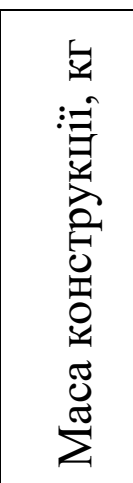 } & \multirow{2}{*}{ 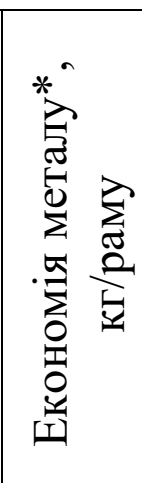 } & \multirow{2}{*}{ 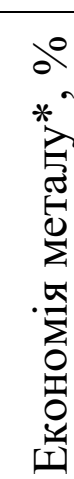 } \\
\hline & $\begin{array}{l}\dot{\Sigma} \\
\dot{\underline{T}} \\
\dot{\Sigma}\end{array}$ & $\begin{array}{l}\frac{T}{z} \\
\bar{z}\end{array}$ & 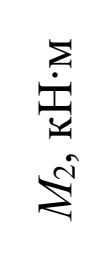 & $\begin{array}{l}\vec{z} \\
\hat{z}\end{array}$ & 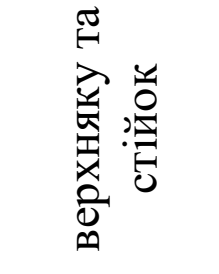 & 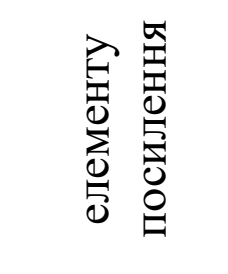 & & & \\
\hline \multicolumn{10}{|c|}{ Несуча здатність кріплення $P=330$ кН } \\
\hline згідно [11] & 31,6 & 15,1 & 14,8 & 15,1 & $150 \times 70 \times 4$ & $160 \times 80 \times 4$ & 193,3 & 274,2 & 59 \\
\hline ВРПП & 19,6 & 16,0 & 8,1 & 16,0 & $110 \times 70 \times 4$ & $120 \times 80 \times 4$ & 156,1 & 311,4 & 67 \\
\hline \multicolumn{10}{|c|}{ Несуча здатність кріплення $P=250$ кН } \\
\hline згідно [11] & 23,9 & 11,4 & 11,5 & 11,4 & $120 \times 80 \times 4$ & $140 \times 100 \times 4$ & 175,6 & 202,4 & 54 \\
\hline ВРПП & 14,9 & 12,1 & 6,13 & 12,1 & $100 \times 50 \times 4$ & $110 \times 60 \times 5$ & 130,0 & 248,0 & 66 \\
\hline \multicolumn{10}{|c|}{ Несуча здатність кріплення $P=180$ кН } \\
\hline згідно [11] & 17,2 & 8,22 & 8,3 & 8,22 & $110 \times 60 \times 4$ & $120 \times 80 \times 4$ & 147,3 & 159,3 & 52 \\
\hline ВРПП & 10,7 & 8,7 & 4,42 & 8,7 & $80 \times 70 \times 3$ & $90 \times 80 \times 4$ & 100,3 & 206,3 & 67 \\
\hline \multicolumn{10}{|c|}{ Несуча здатність кріплення $P=150$ кН } \\
\hline згідно | & 14,3 & 6,85 & 6,9 & 6,85 & $110 \times 70 \times 3$ & $120 \times 80 \times 3$ & 119,2 & 149,6 & 56 \\
\hline ВРПП & 8,92 & 7,25 & 3,68 & 7,25 & $90 \times 50 \times 3$ & $100 \times 60 \times 3$ & 91,5 & 177,3 & 66 \\
\hline
\end{tabular}

*Примітка. Економія металу розрахована у порівнянні з базовою конструкцією 3 профілю СВП, яка завантажена зовнішніми зусиллями згідно [11]. 
Як показали дослідження (табл. 2), використання для кріплення КРТП коробчастого профілю дає змогу зекономити від 52 до 59 \% металу у порівнянні 3 базовою конструкцією з профілю СВП, завантаженою по схемі [11]. Якщо ж у покрівлі виробки виконати вибухове розвантаження порід, зовнішнє навантаження на кріплення стане ще більш сприятливим і економія металопрокату зросте до 66-67 \%. Таким чином, вибухове розвантаження порід покрівлі при використанні коробчастого профілю прокату для несучих елементів кріплення забезпечить економію металу від 177,3 до 311,4 тон на кожному кілометрі виробки у порівнянні з кріпленням зі спецпрофілю СВП без застосування ВРПП.

Проведені дослідження дозволяють перейти до оцінок ефективності кріплення КРТП з різними варіантами конструювання несучих профілів. В роботі [4] для порівняння різних конструкцій кріплення запропоновано використовувати параметр працездатності $\Pi_{w}$, який дозволяє враховувати в узагальненому вигляді особливості деформаційно-силової його характеристики, - величину несучої здатності $P$, кН і конструктивну піддатливість $U$, м, віднесені до загальної маси кріплення $m$, кг:

$$
\Pi_{w}=\frac{\mathrm{P} \cdot U}{m}, \frac{\kappa \mathrm{H} \cdot \mathrm{M}}{\kappa \Gamma},
$$

Чим вище параметр працездатності кріплення $\Pi_{w}$, тим більш раціонально використовується метал в його конструкції, тим воно ефективніше. Фізичний сенс цього показника полягає у тому, що він одночасно відображає головні параметри конструкції при її взаємодії з масивом, тобто несучу здатність і деформованість в податливому режимі, які треба максимізувати. 3 іншого боку, в показнику $\Pi_{w}$ врахована витрата матеріалу в конструкції, причому кріплення тим ефективніше, чим менше його маса. Зручність практичного застосування показника $\Pi_{w}$ для кріплення різних конструкцій полягає в тому, що параметри, які до нього входять легко визначаються з випробувань кріплення або його розрахунку.

Оскільки в даних дослідженнях податливість кріплення $U$ у всіх випадках однакова, виключимо цей параметр з формули (3) і розрахуємо параметр $\Pi_{w}$ для всіх варіантів роботи та конструювання КРТП, які вивчались. Результати розрахунку представлені на графіку (рис. 4).

Проведені порівняльні розрахунки з оцінки параметру працездатності $\Pi_{w}$ кріплення КРТП показали (рис. 4), що найбільш ефективною є конструкція з несучими елементами з коробчастого профілю прокату, у покрівлі якої виконано вибухове розвантаження порід. Показник такого кріплення $\Pi_{w}$ (рис. 4 , лінія 4) у 2,9-3 рази більше у порівнянні з кріпленням зі спецпрофілю СВП такої саме несучої здатності, завантаженого по схемі [11] (рис. 4, лінія 1). Це значить, що метал у першому випадку використовується у 2,9-3 рази ефективніше, ніж у другому. 
$\Pi_{\mathrm{w}}, \mathrm{kH} / \mathrm{kr}$

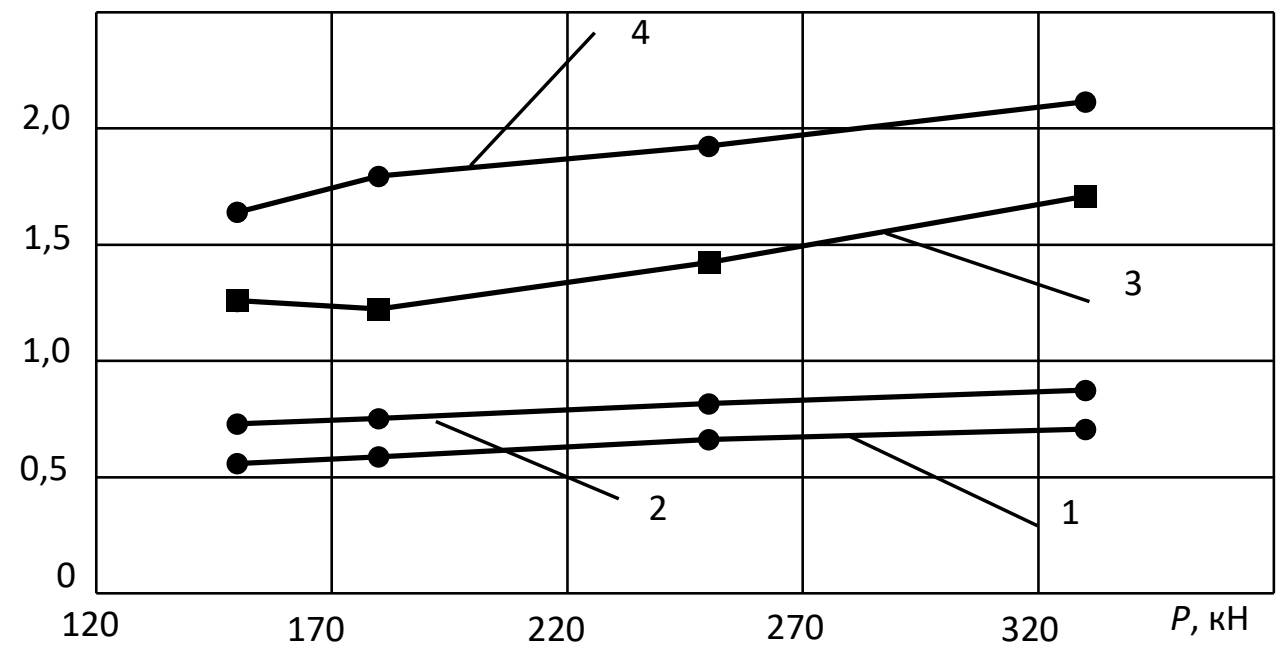

Рис. 4. Залежність параметра працездатності кріплення $\Pi_{w}$ від несучої здатності $P$ з різними варіантами зовнішнього навантаження та типами несучих профілів: 1 - 3 профілю СВП та навантаженням, згідно [11], 2 - 3 профілю СВП та вибуховому розвантаженні порід покрівлі, 3, 4 - з навантаженням, як 1, 2 відповідно, але несучі профілі - коробчасті

Висновки. Досліджена робота та обгрунтовані параметри конструкції рамного податливого трапецієподібного посиленого кріплення з центральною стійкою підвищеного опору (КРТП) під дією параболічного навантаження та навантаження, сформованого вибуховим розвантаженням порід покрівлі (ВРПП) при конструюванні елементів 3 профілю СВП та коробчастого профілю прокату. Доведено, що використання способу ВРПП у всіх випадках підвищує ефективність використання рамного кріплення. Так, при виготовленні кріплення зі спецпрофілю СВП, ВРПП зменшує витрату металопрокату на $20 . .23 \%$ при тій самій несучій здатності, що дає економію від 63 до 89,5 тон на кожному кілометрі виробки. Використання у якості несучих елементів замкнутого коробчастого профілю прокату дозволяє більш ефективно підбирати типорозміри елементів кріплення, що значно підвищує працездатність конструкції, а застосування ВРПП дає суттєву економію металу. У порівнянні з базовою конструкцією (спецпрофіль СВП, параболічне навантаження) витрата металопрокату зменшується на $66 . .67 \%$, або на 177,3...311,4 тони на кілометр гірничої виробки.

Таким чином, доведено, що найбільш ефективним із варіантів, які порівнювались, виявилось кріплення з коробчастого профілю прокату, у покрівлі якого виконано вибухове розвантаження порід. Це підтверджено розрахунками працездатності конструкцій $\Pi_{w}$, які досліджувались.

\section{Перелік посилань}

1. Бабиюк Г.В. (2012). Управление надежностью горных выработок. Світ книги.

2. Павлов, Є. С. (2009). Анализ негативных последствий переборов при проходке горных выработок. Збірник наукових праџь Донбаського державного технічного університету, 28, $125-133$. 
3. Литвинский Г.Г., Гайко Г.И. \& Кулдыркаев Н.И. (1999). Стальные рамные крепи горных выработок. Техника.

4. Литвинский Г.Г. \& Фесенко Э.В. (2014). Разработка и исследование конструкции рамной трапециевидной усиленной крепи. Матеріали міжнародної конференції «Форум гірників $-2014 », 2,121-129$.

5. Литвинский Г.Г. \& Фесенко Э.В. (2013). Исследование параметров рамной крепи из коробчатого профиля. Збірник наукових праць Донбаського державного технічного універcumemy, 41, $5-12 . \quad$ http://www.irbis-nbuv.gov.ua/cgi-bin/irbis_nbuv/cgiirbis_64.exe?C21COM=2\&I21DBN=UJRN\&P21DBN=UJRN\&IMAGE_FILE_DOWNLOAD= $1 \&$ Image file_name=PDF/sntdgtu_2013_41_3.pdf

6. Литвинский Г.Г. \& Фесенко Э.В. (2014). Обоснование конструкции и параметров рамной крепи из коробчатого профиля. Збірник наукових праць Донбаського державного технічного університету, 42, 23 - 30. http://www.irbis-nbuv.gov.ua/cgi-bin/irbis_nbuv/cgiirbis_64.exe?C21COM=2\&I21DBN=UJRN\&P21DBN=UJRN\&IMAGE_FILE_DOWNLOAD= $1 \&$ Image file_name $=$ PDF/sntdgtu_2014_1_5.pdf

7. Фесенко Э.В. (2018). Исследование параметров рамных трапециевидных усиленных податливых крепей. Матеріали міжнародної конферениії «Форум гірників - 2018», 128 - 135.

8. Литвинский Г.Г. \& Фесенко Э.В. (2012). Исследование эффективности прокатных профилей для рамной крепи горных выработок. Уголь Украuны, (11), 11 - 14. http://www.irbisnbuv.gov.ua/cgi-bin/irbis_nbuv/cgiirbis_64.exe?C21COM=2\&I21DBN=UJRN\&P21DBN=UJRN\&IMAGE_FILE_DOWNLOAD= $1 \&$ Image file_name $=$ PDF/ugukr_2012_11_4.pdf

9. Литвинский Г.Г. \& Фесенко Э.В. (2013). Оптимальный прокатный профиль для рамной крепи. Вісті Донецького гірничого інституту, 1(32), 198 - 203. http://ea.donntu.edu.ua/bitstream/123456789/18210/1/\%D0\%98\%D0\%B7\%D0\%B2\%D0\%B5\%D1\%81\%D1\%82\%D0\% B8\%D1\%8F\%201(32)\%202013.pdf\#page $=200$

10. Литвинський, Г. Г. \& Павлов, С. С. (2009) Повышение работоспособности рамной крепи путём взрывной разгрузки пород. Збірник наукових праць Донбаського державного технічного університету, 29, 12-20.

11. СОУ 10.1.00185790.011:2007 Підготовчі виробки на пологих пластах. Вибір кріплення, способів $і$ засобів охорони. (2007). Мінвуглепром України.

\section{АННОТАЦИЯ}

Цель. Изучение особенностей и эффективности работы крепи рамной трапециевидной усиленной с центральной стойкой повышенного сопротивления с различным типом несущих профилей под действием внешней нагрузки.

Методы исследования. Проведено численное моделирование методом конечных элементов с помощью программного комплекса Лира. Использована модель крепи в виде плоской рамы, загруженной внешними усилиями, приложенными к верхняку. Проанализировано напряженно-деформированное состояние опасных сечений конструкции с помощью определения в них значений внутренних силовых факторов.

Результаты. На основе разработанной методики и расчетной схемы проведено сравнение эффективности работы рамной трапециевидной усиленной крепи с центральной стойкой под действием различных видов внешней нагрузки и с использованием различных типов несущих элементов конструкции. Рассчитана несущая способность крепи, проведен подбор и конструирование несущих элементов. Рассчитан параметр работоспособности каждого из рассмотренных вариантов крепи, который позволил обосновать целесообразность применения взрывной разгрузки пород кровли для повышения эффективности работы крепи. 
Научная новизна. Разработаны расчетная схема и методика для определения несущей способности рамной трапециевидной крепи с центральной стойкой под действием различных типов внешней нагрузки. Проведен анализ конструкции с использованием предложенного параметра работоспособности и доказана целесообразность взрывной разгрузки пород кровли с применением коробчатого замкнутого профиля проката для повышения эффективности работы рамной крепи.

Практическое значение. На основе предложенной расчетной схемы проведен анализ работы рамной трапециевидной крепи с центральной стойкой, который позволил обосновать величину несущей способности крепи в различных условиях ее работы, провести конструирование и подбор типоразмеров несущих элементов, доказать, что использование для несущих элементов крепи замкнутого коробчатого профиля с взрывной разгрузкой пород кровли обеспечит существенную экономию металлопроката, которая может достигать 300 и более тонн на километр выработки.

Ключевые слова: рамная крепь, численное моделирование, горное давление, несущая способность, несущий элемент, работоспособность.

\begin{abstract}
Objective. Study of the features and efficiency of the trapezoidal frame support reinforced with a increased resistance central pillar with various types of bearing profiles under the action of an external load.

Research methods. Numerical simulation by the finite element method was carried out using the Lira software package. A model of support was used in the form of a flat frame loaded with external forces applied to the beam. The stress-strain state of dangerous sections of the structure is analyzed by determining the values of internal force factors in them.
\end{abstract}

Findings. On the basis of the developed methodology and the design diagram, a comparison was made of the frame trapezoidal reinforced support efficiency with the central pillar under the action of various types of external loads and using various types of load-bearing structural elements. The bearing capacity of the support was calculated, the selection and design of the bearing elements was carried out. The performance parameter of each of the considered supports was calculated, which made it possible to substantiate the expediency of using the explosive unloading of roof rocks to increase the efficiency of the support.

The originality. A design diagram and a method for determining the bearing capacity of a trapezoidal frame support with a central pillar under the action of various types of external load have been developed. The analysis of the structure is carried out using the proposed performance parameter and the expediency of explosive unloading of roof rocks using a box-shaped closed section is proved to increase the efficiency of the frame support.

Practical implications. On the basis of the proposed design diagram, an analysis of the work of a frame trapezoidal support with a central pillar was carried out, which made it possible to substantiate the value of the bearing capacity of the support in various conditions of its operation, to accomplish the designing and select standard sizes of load-bearing elements, and is proved that the use for loadbearing support elements the closed box-shaped profile with explosive unloading roof rocks will provide significant savings in rolled metal, which can reach 300 tons or more per kilometer of production.

Key words: frame support, numerical simulation, rock pressure, bearing capacity, load-bearing member, working capacity. 